\title{
Intelligent Arabic text to Arabic Sign Language Translation for Easy Deaf Communication
}

\author{
A. E. E. El Alfi \\ Dept. of Computer Science \\ Faculty of Specific Education \\ Mansoura University, Egypt
}

\author{
M. M. R. El Basuony \\ Dept. of Computer Science \\ Faculty of Specific Education \\ Damietta University Egypt
}

\author{
S. M. El Atawy \\ Dept. of Computer Science \\ Faculty of Specific Education \\ Damietta University Egypt
}

\begin{abstract}
This paper presents an intelligent system to translate Arabic natural language to Arabic sign language based on knowledge base and image processing. This system was designed to help hearing impaired for improving their connection with hearing world and acquiring new concepts. The system plays a role for assisting teachers in sign language domain. Of the most important problems in this task, is that the number of words in the Arabic sign dictionary is very few compared with the words found in the Arabic language dictionaries. To solve this problem the proposed system includes a knowledge base to solve a number of Arabic language problems (e.g synonyms, inflectional, derivational, diacritical and plural).
\end{abstract}

Keywords: Deaf, Hearing Impaired, Arabic Sign Language (ArSL), Arabic language, Knowledge Base, Machine Translation, Interpretation.

\section{INTRODUCTION}

Sign language (SL) is the communication media for many deaf people in many countries. According to the World Federation of the deaf, $80 \%$ of deaf people are under educated or illiterate [1]. Deaf people were facing many difficulties in education and when communicating with other hearing people[2]. This makes SL a very important communication media for deaf [3]. There are differences in semantic and syntax between the phonetic language and the sign language[4].

Arabic language morphology is much richer than English[5]. Arabic language is considered as the most category complex natural language [6]. This makes it more complicated in the process of automatic processing.

Most of prominent targets for schools of hearing impaired education in Egypt are helping deaf students identify environment [7].

By combining a specific hand shape, palm orientation, and movement in a particular location, one makes a sign [8]. However SL is considered as the native language for deaf [9]. Arabic Sign Language (ArSL) is used in Arab countries. The unified Arab sign dictionary has been launched for the deaf in two parts in February 2007. It includes 1600 sign [10]. Arabic sign language is used approximately by 3,000,000 deaf in Egypt [11].

Deaf need interpreters to communicate with hearing people. They depend on interpreters for access to information. Interpreters were used to acquire the linguistic and cultural knowledge which underpins their professional skills [12].
Translation into ArSL faces several problems. They can be stated as follows;

- Lack of linguistic studies on ArSL, especially in regard to grammar and structure.

- Large size of the translation corpus while building an ArSL translation system.

- $\quad$ Representing output sign sentences [13] .

- Finding a way to evaluate any SL translation system output [14].

Translation of text language into sign language is an important issue that many researchers have worked on. Masaaki Tokuda and Manabu Okumura had presented a prototype for translation named "SYUWAN" which translates Japanese into Japanese sign language. SYUWAN applies several techniques to find a similar word from a Japanese dictionary and substitutes this word for the original word [15]. However this system doesn't support the Arabic language. Srisavakon Dangsaart et al presented an Intelligent Thai text - Thai sign translation for language learning (IT2STL) [9]. In the translation process, the distinction between Thai text and Thai sign language in both grammar and vocabulary are concerned in each processing step to ensure the accuracy of translation. However, the grammar of Thai language is highly deferent from grammar's Arabic language.

Luis Fernando et. al had presented a system to translate Spanish language into Spanish sign language. The system presented a technique for creating a new language model based on statistical machine translation [16].

A translation system for Arabic sign language was developed by Abdul Aziz et. al [17]. They presented a machine translation system for translating text into ArSL. The system has two phases. Phase 1 is run only once; it pre-compiles the chunks and their associated signs. Phase 2 is the actual translation system that converts Arabic input into ArSL output. However, this work was implemented by using the output in conjunction with the distance. Although, Google was announced at the end of 2011 about Google tashkeel service was stopped. Ameera M. Almasoud and Hend S. AlKhalifa presented a system for translating Arabic text to ArSL in the jurisprudence of prayer domain. The system is composed of a set of processes, namely: morphological analysis, grammatical transformation and semantic translation[3]. However; that work was considered as ontology work and not application. ArSL systems were presented to translate word by word, [18-22]. However; they didn't consider the semantics of the translated sentence or the translation rules of Arabic text to ArSL. 
This paper presents a proposed system for translating Arabic text to ArSL. It is based on a knowledge base to solve a number of Arabic language problems such as synonyms, inflectional, derivational, diacritical, and plural. Also the system includes finger spelling translation to overcome the problem of words didn't exist in the database. In general, this system aims to translation from Arabic language to ArSL for improving the communication between deaf and hearing people.

This paper is organized as follows; section 1 is the introduction, section 2 the proposed system architecture, section 3 explains the system description, section 4 presents the experimental, results, finally section 5 includes conclusion and future work.

\section{Difficulties in ArSL}

ArSL differs from Arabic language and other spoken languages, in its own lexicon and grammar rules. ArSL is similar to other world sign languages in that they are basically spatial-gestural languages. This makes it difficult to compare sign languages with their spoken counterparts. Arabic in this regard is not an exception. As a matter of fact, many concepts used to describe spoken languages are inadequate for the description of sign languages. Nevertheless, inevitably, one system should be mapped practically into the other [23]. There is no singular, dual, or plural agreement in ArSL signed sentences, as shown in table 1. In Arabic language, many nouns are countable, but it does not in ArSL. For example the word "كتابين are expressed in sign language by two words; "كتاب" and then sign of the number "اثنان", in order to denote the dual.

Table 1 Combination in ArSL

\begin{tabular}{||l||l||l||l||}
\hline \hline No & $\begin{array}{l}\text { Arabic language } \\
\text { syntax }\end{array}$ & ArSL syntax & \\
\hline \hline 1 & Singular & Singular & agree \\
\hline \hline 2 & Dual & Singular+2 & $\begin{array}{l}\text { Doesn't } \\
\text { agree }\end{array}$ \\
\hline \hline 3 & Plural & Singular +3 & $\begin{array}{l}\text { Doesn't } \\
\text { agree }\end{array}$ \\
\hline
\end{tabular}

On the other hand, ArSL does not make use of tense aspect as in spoken and written varieties. Tense in ArSL is simply and practically used. Past, present, and future tenses are indicated at the beginnings of conversation chunks and only shifted when there is a need to indicate a different tense. Negatives and interrogatives have more than one way of expression. While in some cases no manual as for other grammatical features like emphasis and adverb position. Emphasis is done by repetition, longer signing time, facial expressions, and dramatization. Adverbs are explained manually, by one hand's position in relation to the other. Other features, such as passivation, and declension, are nonexistent. Conditional expressions, sentence boundaries, and turn taking are usually achieved by nominal features of facial expressions and context[24]. Table 2 shows some syntax differences between Arabic language and ArSL.
Table 2 Some differences between Arabic language and ArSL

\begin{tabular}{|l||l||l||}
\hline No & Arabic syntax & ArSL syntax \\
\hline \hline 1 & S+V & S+V \\
\hline \hline 2 & V+S & S+V \\
\hline \hline 3 & S+P & S+P \\
\hline \hline 4 & S+V+O & S +O+V \\
\hline \hline 5 & S+ V+O (Adj, Adv) & S + O + V (Adj, Adv) \\
\hline \hline 6 & S+P + (Adj, Adv) & S+P +(Adj ,Adv) \\
\hline \hline 7 & S+ V+ Pr & S+V \\
\hline \hline 8 & V+O & O+V \\
\hline
\end{tabular}

Where; Subject $(\mathrm{S})$, Verb $(\mathrm{V})$, Object $(\mathrm{O})$, Predicate $(\mathrm{P})$, Adjective (Adj), Adverb (Adv), and Pronoun (Pr).

Sentence structure in SL is simultaneous with a parallel temporal and spatial configuration while language is linear; one word followed by another [10]. The structure of Arabic sentence is divided into two types of sentences. Generally, it contains Subject, Verb, Object and Predicate, in a sequence that differs from ArSL as shown in table 2. Sometimes, the Arabic sentence structure starts with subject and sometimes starts with verb. However it is preferable to begin the ArSL sentence with subject, such as:

is translated into:

$$
\text { " قام المعلم بإعطاء درس فى الحساب " }
$$

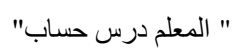

The ordering of a negative sentence of ArSL is not similar to the sentence in Arabic language. Additionally translation of adjective can be done either by using the adjective sign directly (if it exist in the dictionary), or by using negation of an equivalent negative verb to the adjective. For example the word such as "وفاء" does not need to be the word "غدر" as shown in Table 3.

Table 3 Negative sentence [9]

\begin{tabular}{||l||l||l||}
\hline \hline & Arabic syntax & ArSL syntax \\
\hline \hline 1 & Neg + V & V + Neg \\
\hline \hline 2 & S+Neg+V+O & O+ S+V+Neg \\
\hline \hline 3 & S + Neg + V & S + V + Neg \\
\hline \hline 4 & Neg + (Adj, Adv) & (Adj, Adv) + Neg \\
\hline \hline 5 & Adj & V + Neg \\
\hline
\end{tabular}




\section{THE PROPOSED SYSTEM ARCHITECTURE}

The goal of this system is build a knowledge base for the translation of Arabic text into ArSL for making the communication between deaf and normal people simple, easy, and flexible.

The architecture of the intelligent system for translating Arabic text sentence into ArSL is shown in figure 1.

The translation is performed by four main stages: The parser, Intelligent text treatment, sign-code selection, and sign image retrieval.

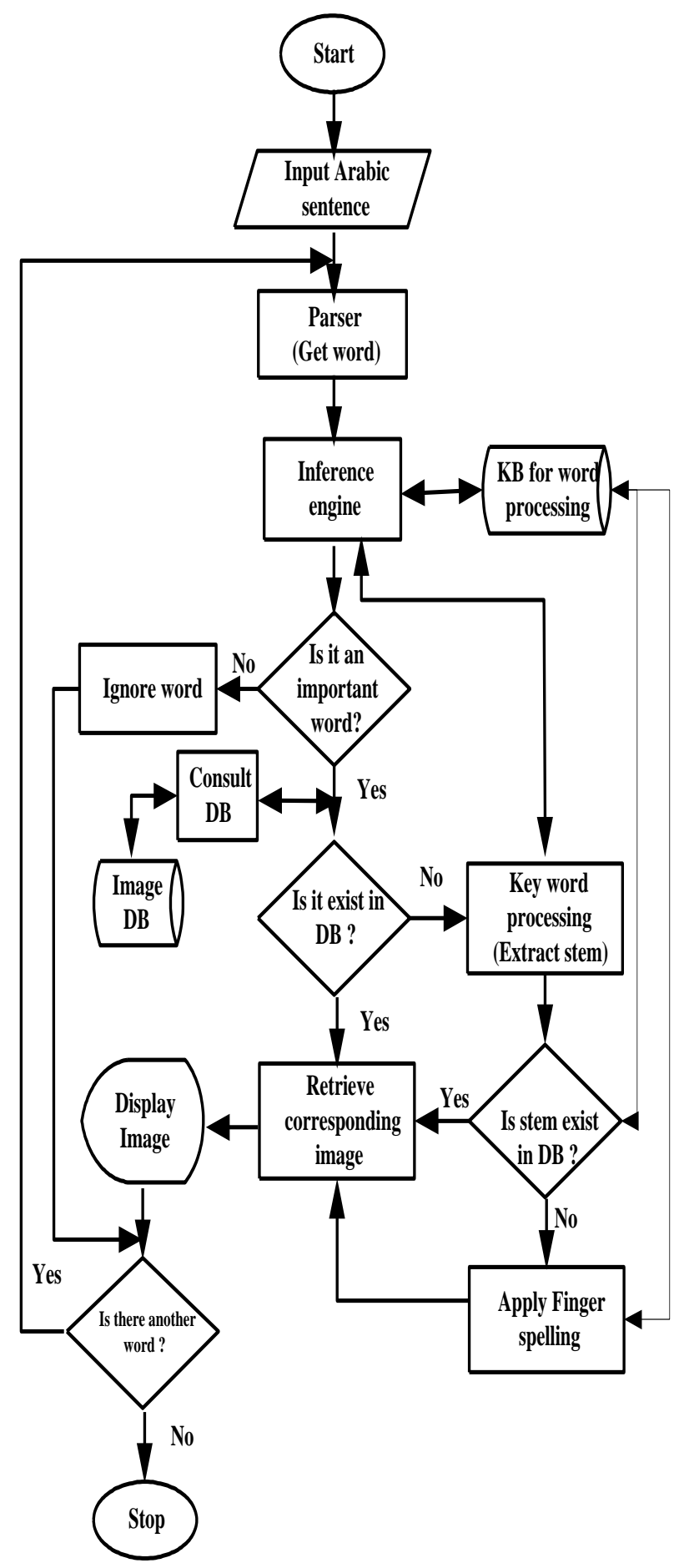

Figure 1 flowchart for translating Arabic sentence into Arabic sign language

\section{SYSTEM DESCRIPTION}

The details description of the proposed system is discussed in the following section.

\subsection{The parser}

It receives input in the form of sequential text and breaks it up into parts (for example, the nouns (objects), verbs (methods), and their attributes or options) that can be managed by other programming [25-26].

The input text is divided into a sequence (SQ) of words; w1, w2 $2, \ldots \ldots$ wn.

R \#: Divided the sentence into several words.

$\mathrm{R} \#$ : Analysis of the word to several letters.

\subsection{Intelligent text treatment}

Some of the problems that deal with natural language interpretation (writing style, vocabulary, spelling, synonyms, derivational and other things) are formulated in knowledge base. Some of the rules can be stated as follows;

\subsubsection{Rules to delete special characters}

Arabic language contains some special characters that do not affect the meaning of a sentence such as

( \&,*,!,\%,,,\$,@, ?,:, ",\#,..........).

So some rules are derived to delete these special characters.

\subsubsection{Rules to delete stop words}

Stop words are very common words that appear in the text to carry little meaning. They serve only a syntactic function but don't indicate subject matter [27].

So the system has to delete the stop words in order to focus on the core content within text.

Stop words such as:

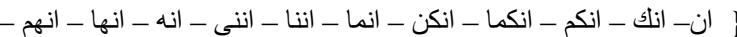

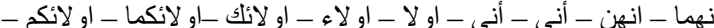

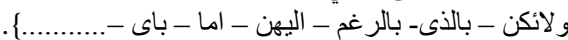

\#: IF the word is not important such as:

$$
\text { " سيد - سيدة- استاذ- استاذة - انسة - مدام" " }
$$

THEN delete it from the sentence.

R\#: IF the word indicates plural, such as:

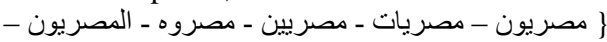$$
\text { المصريات ـ المصريين - المصروهات ـ مصرين }
$$

THEN place it in one group and strip offit to their origin. R\#: IF the word is the relative pronouns such as: \{ الذا ـ الذى - التى_ الذان- اللتان- اللتين- الذين

THEN delete it.

R\#: If the word is one of demonstrative pronouns, such as:

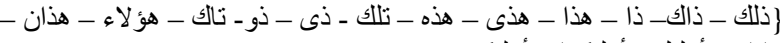
هاتان - أولئك ـ أولئكما - أولنئكم

THEN delete it.

R \#: IF the word is

$$
\text { \{ انه ـ انهما - انهم - انها - انهن - انك- انكما- انكم - ان- انكن- انى }
$$

THEN delete it.

$\mathrm{R}$ \#: IF the word is

$$
\text { \{اياى - اياك - اياكما - ايانا - اياكم ايكن }
$$




\section{THEN deleted.}

$\mathrm{R}$ \#: IF the word indicates advocated such as

THEN delete it.

$$
\{\text { \{ أيتها-با - أيها }
$$

$\mathrm{R}$ \#: IF the word is

THEN delete it.

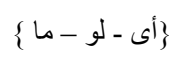

R \#: IF the sentence contains two corresponding words, THEN delete once.

R \#: IF the word is" كان" or some of her sisters was such as: THEN delete it .

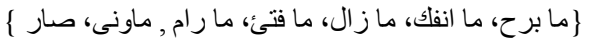

Although they affect the grammatical rules, but it does not affect the meaning of the sentence.

\subsubsection{Rules to retain exception words}

Exception words are the words that change the sentence meaning. Exception words such as

$$
\text { \{ الا , غير , سوى , ماعدا , ماخلا , ماحاشل }
$$

\subsubsection{Rules for characters unification}

Arabic language includes some letters that can be written indifferent formats. This causes the complexity of the programming process. Consequently one must unifies the forms of the characters such as the following forms: Aleph

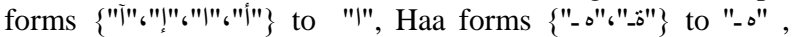

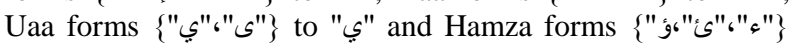
to $\{\varsigma\}$.

R \#: IF the word contains Hamza in different forms such as:

Then substitute by " أ ".

$$
\text { "أ- إ- ا- ؤ- \&- ني" }
$$

\subsubsection{Rules for spell checking}

There are common word spelling errors that can be arisen during deaf writing. The errors and their corrections errors looks like:

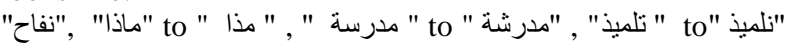

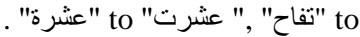

And so any other words needed to be checked.

\subsubsection{Rules to unify synonyms}

Arabic language has rich derivative synonyms such as:

$$
\text { \{ هاتف, تللفون, جو ال, محمول }
$$

As well as verbs such as:

$$
\text { \{ يحب , يغرم ب , يشغف , يتوق }
$$

So the system solves this problem by doing a simple dictionary for a number of equivalent synonyms in Arabic.

R\#: IF word contain possessive pronouns such as:

$$
\text { \{كتابى - كتابه كتابك- كتابهم كتابكم - كتابكما- كتابهن- كتابهما }
$$

Then strip off word to "كتاب".

$\mathrm{R}$ \#: IF the abstract word has several synonyms such as:

$$
\{\text { \{يحب - يود - ينوق - يغرم - يشغف\} }
$$

Then substitute the word by: "يحب".

$\mathrm{R}$ \#: IF one word is member of the set :

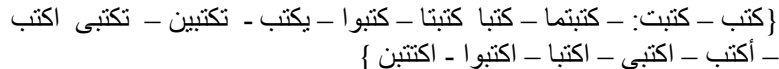

THEN Strip off it to the verb " كتب "

$\mathrm{R}$ \#: IF the word indicates possessive pronouns such as:

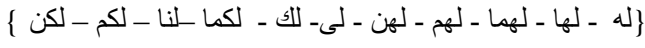

THEN replace it with the verb "يملك" .

$\mathrm{R} \#$ : IF the word indicat any adjective such as:

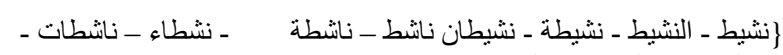

نشيطنان- نشيطون -نشيطات

THEN strip off it into "النشاط" .

\subsubsection{Negative expressions}

Arabic negation is the process that turns an affirmative statement into its opposite denial, such as:

$$
\text { • - م الطفل يشرب اللبن }
$$

There is a difference between the meanings of the two sentences. The second sentence gives meaning opposite to the first sentence.

$\mathrm{R} \#$ : IF the word is member of:

Then substitute the word by "ليس".

$$
\{\text { \{ لا لا لم , لن, ما, ليس }
$$

Arabic languages used the negation 'ma' plus 'sh' "ماش" for negated word for example $\{$ ماعرف

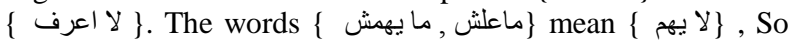
the system maintained and converts all negation expressions to meaning " $"$ " too.

\subsubsection{The expressions $O R \& A N D$}

Arabic meaning of the expression including " for the OR relation and " 9 " for the AND relation gives two different meaning for example:

$$
\begin{aligned}
& \text { • الطفل يشرب الثاى أو اللبن } \\
& \text { • الطفل يشرب الثاى و اللبن }
\end{aligned}
$$

First meaning expresses the OR logic choice between things and while the second meaning to expresses the AND logic combine between things, so this system retains the meaning of each expression.

\subsubsection{Retain pronouns}

There are three pronouns in Arabic language such as: first person, such as:

the second person such as:

the third person such as:

$$
\text { " انت , انتما , انتم, انتن " }
$$

These types of words must be retained

\subsubsection{General rules}

There are also some difference between Arabic language and the other language. Some of these differences can be treated by the following rules:

R \#: IF the word indicates names that refers number such as:

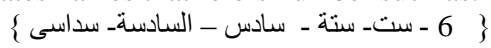

Then substite the numeric integer itself. 
$\mathrm{R}$ \#: IF the word includes preposition and possessive pronouns like "بدرستتا"

THEN stripe it into " مدرسة"

$\mathrm{R}$ \#: IF the word is member of the following

THEN substite the word by " ظن".

$$
\text { \} }
$$

$\mathrm{R}$ \#: IF the word is conjunction such as:

$$
\text { \{ حتى - ف بالاضافة الى ذلك_ كذلك- ثم- اذا }
$$

THEN divide the sentence into simple sentences.

$\mathrm{R}$ \#: IF words are consistent in drawing and differ in meaning, such as:

THEN treat it according to its diacritical.

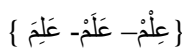

$\mathrm{R}$ \#: IF the word indicates result such as:

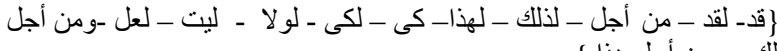$$
\text { ذلك - من أجل هذا }
$$

THEN divide the sentence into simple sentence.

$\mathrm{R} \#$ : IF the word is member of:

THEN replace it into "نعم".

$$
\text { which indicate agreement }\{\text { نعم - بلى - أجل }
$$

R \#: IF the word indicates double such as " تلميذتان" or plural such as "تلميذات"

THEN the words as follows;

Single "تلميذة" plus a number 2 for double or number 3 for plural.

\section{Morphological Analyses}

Arabic language is based on root-pattern schemes. Using one root, the language can generate tens or hundreds of words.

The roots have commonly three or four letters and in rarely case five letters [28].

Arabic language has also high degree of ambiguity due to missing of vowels and similarity among derivatives. Analyzing words to their stems is more useful when dealing with plural, dual, suffix, and prefix.

The studies [29-32] have reported method to stem by deleting any prefixes and suffixes.

In order to get word stem the following steps will be done:

- Split the word into character.

- Delete prefixes such as:

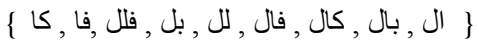

- Delete suffixes such as:

\begin{tabular}{|c|c|c|c|c|c|c|}
\hline ID & First & Scand & Third & Forth & Fifth & $\begin{array}{c}\text { The } \\
\text { template } \\
\text { target }\end{array}$ \\
\hline P1 & شارب & شروب & شر اب & مشروب & مشرب & شرب \\
\hline $\mathrm{P} 2$ & سامع & سموع & سماع & مسموع & مسمع & سمع \\
\hline $\mathrm{p}_{\mathrm{n}}$ & ........ & ........ & ........ & ....... & ........ & ............... \\
\hline
\end{tabular}

$$
\text { \} ون , ين, كن , هن ات, ان, ين , تن تخ , يا , وا , ما, نا, ها }
$$

- Make pattern matching to get the stem.

The stem pattern is shown in table4. The pattern illustrates the derivatives from the verb in Arabic language.
Table 4 Sample of stem pattern

$\mathrm{R}$ \#: IF the word is member of the template.

Then stem is the template target .

Ex : IF the word is member of :

$$
\text { | }
$$

Then stem is "شرب".

\subsection{Sign-code selection}

Intelligent text treatment stage produces the words that match its corresponding signs.

If the word does not have a corresponding sign then replace this word by one of its synonyms that have a sign in the database. If the word does not have a corresponding sign, then use the finger spelling.

\subsection{Sign image retrieval}

The classification of digital image processing has three distinct classes: low-level vision, intermediate-level vision and high-level vision. High-level vision algorithms use symbolic representations for both input and output [33].

The system in this process takes the previous results of sentence arrangement and displays the corresponding sign images from the image database. If the word does not have a corresponding sign, then it will be represented by finger spell as the following:

- Break word into characters.

- Recall the corresponding sign of characters.

\section{EXPERIMENTAL RESULTS}

The experiment was applied in the "Al-Amal Institute" for teaching deaf at Damietta. The graphical user interface of the proposed system is shown in Figure 2. This figure shows the virtual sign keyboard and some buttons such as (Exit, Clear, and Clear all).

The user enters the sentence in the text box. After s (he) checks the button "Translate". Then is the results of the translation are displayed in the panel "Translation output ".

The total number of selected signs is 137 . These signs were selected by three experts in domain. The total number of Arabic sentences is 101 .

Sample of translation results are shown in table5 


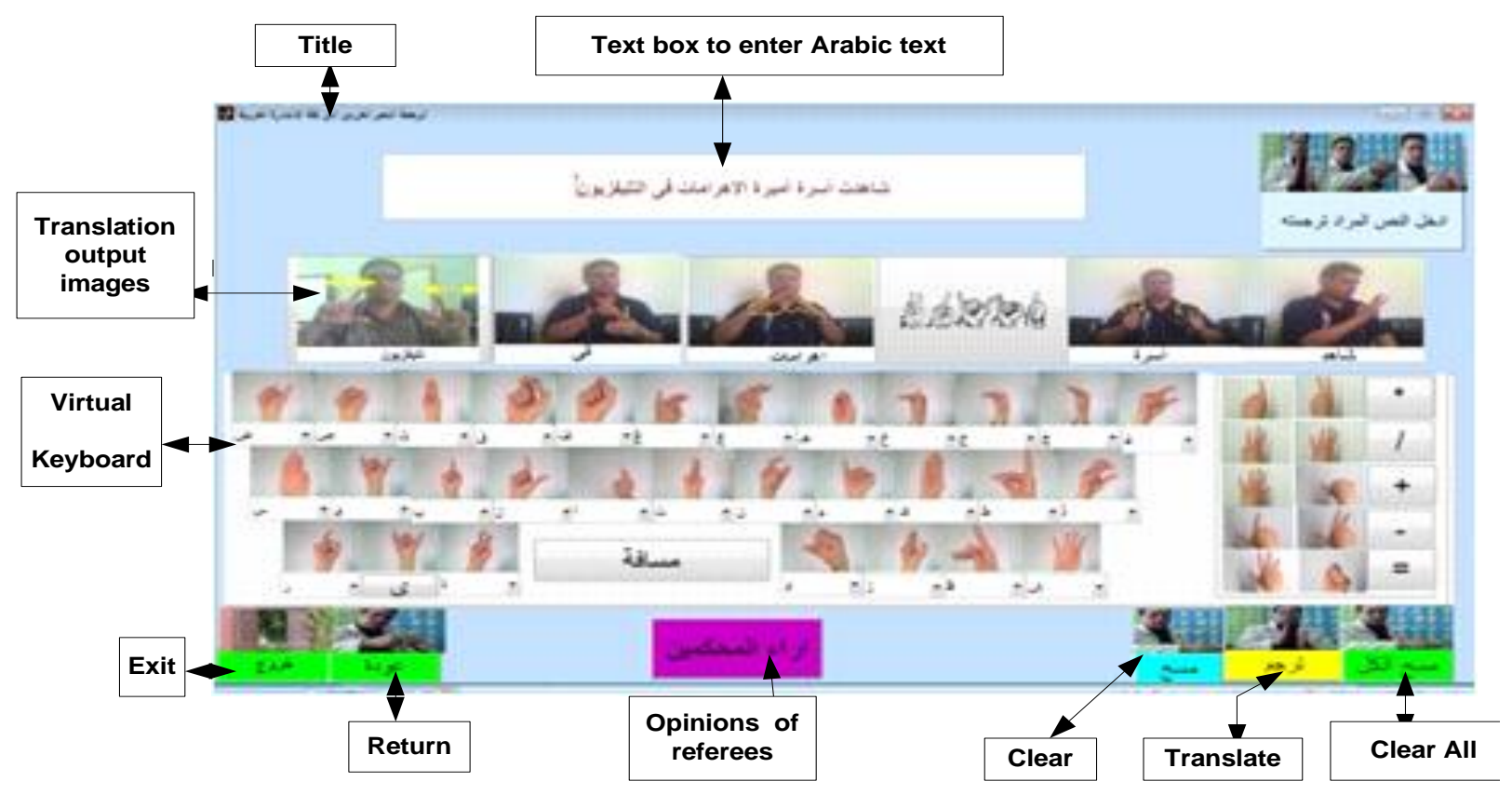

Figure 2:The Graphical user interface of the proposed system

Table 5 Sample of translation results

\begin{tabular}{|c|c|c|}
\hline No & Arabic language & "Arabic sign language images representation \\
\hline 1 & قامت الأم و خفضت الصوت & \\
\hline 2 & كتب أمير فى كُتُب المدرسة & \\
\hline 3 & نصح الأم بعدم تعريض أميرة للأصو ات المرتفعة & \\
\hline 4 & قال الطبيب : ان أذن أميرة تعرضت & \\
\hline
\end{tabular}

\section{- System performance evolution}

The system was tested by five interpreters in deaf domain .Interpreters put their scores for each sentence translated based on (correct sign representation ,transfer the correct meaning, incorrectly translated word, and correct grammar).

The performance evolution of the proposed system was based on (accuracy, precision, recall, and F-measure )[ 9, 34].

Sample of results is shown in table 6.

\begin{tabular}{|c|c|c|c|c|}
\hline \multirow{2}{*}{$\begin{array}{c}\text { No. of } \\
\text { Sentence }\end{array}$} & \multicolumn{4}{|c|}{ Measurement } \\
\hline & Accuracy \% & Precision\% & Recall\% & F. score \% \\
\hline 1 & 90 & 80 & 100 & 88.8 \\
\hline 2 & 90 & 60 & 100 & 75 \\
\hline 3 & 100 & 100 & 100 & 100 \\
\hline 4 & 90 & 60 & 100 & 75 \\
\hline ....... & $\ldots$. & . & .......... & .......... \\
\hline $\begin{array}{c}\text { Total } \\
\text { evaluation }\end{array}$ & 96 & 88.3 & 100 & 97.7 \\
\hline
\end{tabular}




\section{CONCLUSION AND FUTURE WORK}

This work aimed to serve Arabic deaf for easy communication. It is based on a knowledge base to solve a number of Arabic language problems such as synonyms, inflectional, derivational, diacritical, and plural. Also the system includes finger spelling translation.

This system helps listeners to learn sign language easily and allows deaf to develop their experiences. Authors are currently working to build a translation system from Arabic

sign language into Arabic text through image recognition. In addition developing a test for the user checks what gained information.

The future work aims to integrate video processing and text processing in order to get on line sign language translator system.

\section{6-REFERENCES}

[1] World Federation of the Deaf (WFD),Position Paper regarding the United Nations Convention on the Rights of People with Disabilities, Ad Hoc Committee on a Comprehensive and Integral International Convention on the Protection and Promotion of the Rights and Dignity of Persons with Disabilities, 24 June 2003.

[2] Ameera M.Almasoud and Hend S. Al-Khalifa," A Proposed Semantic Machine Translation System for translating Arabic text to Arabic sign language", Second Kuwait Conf. on E-Services and E-Systems, April 5-7, 2011, pp 79-84.

[3] Hend S.AL- Khalifa, " Introducing Sign Language for Mobile phones", Lecture Notes in Computer Science, Volume 6180, pp 213-220, springer, 2010.

[4] Edith A. Moravcsik, "An Introduction to Syntax: Fundamentals of Syntactic Analysis" , 2006 , p.p25, Available: books.google.com.eg/books?isbn...

[5] Aitao Chen and Fredric Gey," Building an Arabic Stemmer for Information Retrieval", Defense Advanced Research Projects Agency (D ARP A),grant number N66001-00-1-8911 (Mar 2000-Feb 2003).

[6] Saad Ibrahim," Arabic language and the importance of Morphology", 2003.Available: http://ccisdb.ksu.edu.sa/files/rep1120000.doc 1.

[7] Ministry of Education: "Ministerial Decree No. 37 dated 11/28/1990 regarding regulation Altnzemih schools and special education classes ", Cairo, presses Rosalyousef, 1990.

[8] Dennis Cokelyand Charlotte Baker," American Sign Language: A Teacher's Resource Text on Curriculum method and evulsion", gallaudes university presses, 1999,pp 3-4.

[9] Srisavakon Dangsaart et al, "Intelligent Thai text - Thai sign translation for language learning", science direct, Computers \& Education 51 ,2008, pp 1125-1141.

[10] Samir Samreen and damper Abanngly," Rules of the Arabic language sign unified", 2010.Available: http://www.scfa.gov.qa

[11] http://elakhbar.akhbarway.com/news.asp?c=2\&id=10358 2 , accessed on 12/12/2012.
[12] jeminanapier et al, " sign language interpreting: theory and Practice in Australia and New Zealand", Sydney, federation presses,2006,pp 9-10.

[13] M. A. Abdel-Fattah, " Arabic Sign Language: A Perspective", Journal of Deaf Studies and Deaf Education vol. 10 no. 2, Spring 2005,pp 212-221.

[14] Abdul aziz Almohimeed et al , " Arabic Text to Arabic Sign Language Translation System for the Deaf and Hearing-Impaired Community", Proceedings of the 2nd Workshop on Speech and Language Processing for Assistive Technologies, Edinburgh, Association for Computational Linguistics, 2011, pp 101-109.

[15] Masaaki Tokuda and Manabu Okumura," Towards Automatic Translation from Japanese into Japanese Sign Language", Springer-Verlag Berlin Heidelberg, Assistive Technology and AI, LNAI 1458, pp. 97-108, 1998.

[16] Luis Fernando D'Haro et al, "Language Model Adaptation for a Speech to Sign Language Translation System using Web Frequencies and a MAP Framework" , ISCA, 2008. P.p 2199- 2202.

[17] Abdul aziz AL Mohamed et al ," A New Evaluation Approach for Sign Language Machine Translation", In Assistive Technology from Adapted Equipment to Inclusive Environments, AAATE 2009, Volume 25, pp 498-502, Florence, Italy.

[18] Mohamed Mohandes and Jamil Bakhshawain ,"Translation of the Arabic Text to Arabic Sign Language Using Computers" ,2006,Available:http://stcex.tvtc.gov.sa/NR/rdonlyres/...F 0AF.../307.pdf.

[19] Sami M. Halawani," Arabic Sign Language Translation SystemOn Mobile Devices", IJCSNS International Journal of Computer Science and Network Security, VOL.8 No.1, January 2008, pp 251-256.

[20] Hanadi Al-Dosri et al," Arabic Sign Language Easy Communicate ArSLEC, ICCIT 2012, pp 274- 279

[21] Mohammed Abo El-Soud et al "A Proposed Web Based Frame work E-Learning and Dictionary System for Deaf Arab Students", International Journal of Electrical \& Computer Sciences IJECS-IJENS Vol: 10 No: 01, 2011, pp 56-68.

[22] Basmah Faraj et al,"Avatar Based Approach for Teaching Arabic Sign Language", J. of Commun. \&Compute. Eng.,Volume 2, Issue 2, 2012, Pp 43: 48.

[23] jeminanapier et al, " sign language interpreting: theory and Practice in Australia and New Zealand", Sydney, federation presses,2006,pp 9-10.

[24] M. A. Abdel-Fattah, " Arabic Sign Language: A Perspective", Journal of Deaf Studies and Deaf Education vol. 10 no. 2, Spring 2005,pp 212-221.

[25] "Text segmentation" , Available :http://www.en.wikipedia.org/wiki/Text_segmentation

[26] Ibrahim Abu El-khair," Effective of stop words elimination for Arabic information retrieval: a comparative study ", international journal of computer \&information science, vol.4 No. 3 , 2006.

[27] Ibrahim A. Al Kharashi and Imad A. Al Sughaiyer , " Performance Evaluation of an Arabic Rule-Based 
المؤتمر الوطنى السابع عشر للحاسب الالى ( المعلوماتية فى "Stemmer المعني

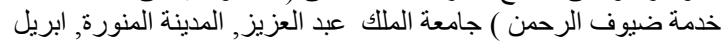
ץ.. ऽ pp 405-414.

[28] Kareem Darwish," Building a Shallow Arabic Morphological Analyzer in One Day"Available:www.cs.umd.edu/Library/TRs/CS.../CSTR-4326.pd

[29] Leah S. Larkey et al , " Improving Stemming for Arabic Information Retrieval :Light Stemming and Cooccurrence Analysis" 2002, Available:ciir.cs.umass.edu/pubfiles/ir-249.pdf.

[30] Eiman Tamah Al-Shammari \&Jessica Lin, Ph.D. ," Towards an Error-Free Arabic Stemming" , 2008, pp 915 , Available: www.cs.gmu.edu/ jessica/.../Arabic_inews08.pdf ,
[31] Youssef Kadri \& Jian-Yun Nie, "Effective Stemming for Arabic Information Retrieval" , THE CHALLENGE OF ARABIC FOR NLP/MT, Available: http//atour.iro.umontreal.ca/rali/sites/.../BCS-2006Kadri.pdf

[32] Aitao Chen \&Fredric Gey , " Building an Arabic Stemmer for Information Retrieval" , 2002, Available :http://citeseerx.ist.psu.edu/.../summary?di.

[33] loannis Pitas ," Digital Image Processing Algorithms and Applications" ,john Wiley \& Sons Inc, 2000.

[34] Dan Melamed et al,"precision and recall of machine translation, Available: nlp.cs.nyu.edu/pubs/papers/hlt03eval.pdf. 